\title{
Piggyback proximal anastomoses provide independent flow to target myocardium
}

Andrea Carpenter, MD, $\mathrm{PhD}$

See related article on pages $725-7$.

Occasionally, someone proposes a technique so simple and obvious, I am tempted to thump my forehead and ask, "Why didn't I think of that?" In describing a piggyback technique for proximal anastomosis using the heartstring device, Dr Yanagawa and colleagues ${ }^{1}$ create just such a moment. Although they are not the only surgeons to envision this technique, ${ }^{2}$ they present an elegant argument for its benefits: the ability to perform a proximal anastomosis using a small conduit without flattening the inflow, improved cost effectiveness with 2-for-1 device use, and clear demonstration of consistent blood flow to all vascular beds involved. The demonstration of consistent blood flow is what provides the most convincing argument for this technique.

Use of the heartstring device to minimize aortic manipulation has been suggested to reduce stroke risk, but agreement is lacking in the literature on this subject. ${ }^{3,4}$ Given this lack, neither the authors of this $\operatorname{article}^{1}$ nor I would propose the piggyback technique with the objective of stroke reduction.

However, I would propose that this method additionally may be very useful in the challenge of managing the short or heavily diseased aorta during on-pump cases.
The data presented ${ }^{1}$ give good evidence that both of the distal coronary beds receive independent flow with this technique. Providing inflow to 2 grafts with limited aortic manipulation seems advantageous, compared with seeking alternative proximal sites, such as the innominate or carotid arteries. Similarly, placing a small

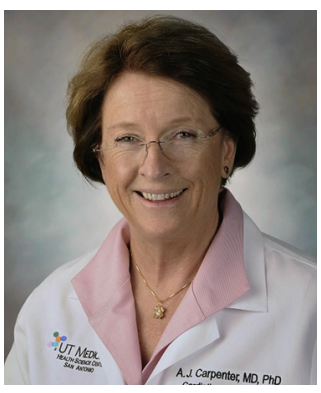
free arterial conduit, radial or right internal thoracic artery, as a piggyback on a vein graft reduces the risk of compromising the left internal thoracic artery inflow by creating y-grafts from this most important conduit.

\section{References}

1. Yanagawa B, Orozco-Sevilla V, Pawale A, Puskas JD. Piggyback technique facilitates off-pump coronary artery bypass graft with the Heartstring III with arterial conduits. J Thorac Cardiovasc Surg. 2015;150:725-7.

2. Niclauss L, Colombier S, Prêtre R. Single heartstring aortotomy for multiple off-pump venous bypass grafts. Asian Cardiovasc Thorac Ann. 2015;23: 609-11.

3. Emmert MY, Seifert B, Wilhelm M, Grünenfelder J, Falk V, Salzberg SP. Aortic no-touch technique makes the difference in off-pump coronary artery bypass grafting. J Thorac Cardiovasc Surg. 2011;142:1499-506.

4. Biancari F. Does anastomosis device or epiaortic ultrasonography reduce the risk of postoperative stroke after coronary artery bypass grafting? J Thorac Cardiovasc Surg. 2012;143:1231-2.

\footnotetext{
From the Department of Cardiothoracic Surgery, University of Texas Health Science Center, San Antonio, Tex.

Disclosures: Author has nothing to disclose with regard to commercial support.

Received for publication May 29, 2015; accepted for publication June 3, 2015; available ahead of print July 3, 2015.

Address for reprints: Andrea Carpenter, MD, PhD, Department of Cardiothoracic Surgery, University of Texas Health Science Center, 7703 Floyd Curl Dr, MC 7841, San Antonio, TX (E-mail: carpentera2@uthscsa.edu).

J Thorac Cardiovasc Surg 2015;150:728

$0022-5223 / \$ 36.00$

Copyright (c) 2015 by The American Association for Thoracic Surgery

http://dx.doi.org/10.1016/j.jtcvs.2015.06.010
} 